\title{
Charcot-Marie-Tooth disease type 1D
}

INSERM

\section{Source}

INSERM. (1999). Orphanet: an online rare disease and orphan drug data base. CharcotMarie-Tooth disease type 1D. ORPHA:101084

Charcot-Marie-T ooth disease type 1D (CMT1D) is a form of CMT1 (see this term), caused by mutations in the EGR2 gene (10q21.1), with a variable severity and age of onset (from infancy to adulthood), that usually presents with gait abnormalities, prog ressive wasting and weakness of distal limb muscles, with possible later involvement of proximal muscles, foot deformity and severe reduction in nerve conduction velocity. Additional features may include scoliosis, cranial nerve deficits such as diplopia, and bilateral vocal cord paresis. 